\title{
The Great War: World war, total war
}

\section{Annette Becker}

Annette Becker is a Professor at Université Paris-Ouest Nanterre. She is also a member of the Editorial Board of the International Review of the Red Cross.

\section{Abstract}

The Great War was globalized and totalized ${ }^{1}$ by the inclusion of colonial and newly independent people from all over the world and of civilians, old people, women and children. The European war became a laboratory for all the suffering of the century, from the extermination of the Armenians to the refugee crisis, the internments, and the unending modernization of warfare.

Keywords: Great War, First World War, total war, occupied territories, prisoners of war, civilians, refugees, civilian internment.

Cartoon of two men camouflaging cannon:

- "You were a decorator before you joined up.

What're you doing nowadays?"

- "Scenery for a tragedy."

The Great War was a total, global tragedy: its setting, the entire world; its duration, 1914-18; its main feature, mass violence. From the very beginning, the British, French, German and Belgian governments made the war global by pulling the inhabitants and resources of their empires into it. This took place long before the United States entered the war in 1917. Countries, whether neutral or not, helped maintain the epic scale of the violence through industrialized production of munitions, food and other supplies, while also seeking to uphold as much of the law of war as they could. Although the war officially ended in 1918, in some ways it continued into the 1920s and lasted right up to the Second World War. 
For the first time in history, the whole world waged war-a war that devoured men, resources and energy; that split loyalties, reignited old fervours and generated new horrors. What began in Europe, and might have been only the "Third Balkan War", was turned into a global catastrophe upon the whim of the great imperial powers. Four of them-Germany, Austria-Hungary, the Ottoman Empire and Russia - were destroyed by it, but the war would also leave a vivid scar on the collective memory of all involved. The world would come to mourn the deaths of hundreds of thousands of civilians and ten million combatants, and the loss of an innocence never to be regained.

In 1918, Maurice Busset produced a large painting entitled Bombardement de Ludwigshafen (Figure 1). He was so proud of his work - in both senses of the word - that he signed it "aviator", a member of the new cavalry of the sky. His own plane can be seen above a factory in flames-bombs falling in a colourful, almost joyful setting in which Busset, a very patriotic man, depicts the destruction of a German factory, perhaps one of those that had produced the asphyxiating gases used on all the battlefields since 1915. What did civilian lives matter - the lives of the workers and residents of the area - when what counted was winning the war? The painting shows that in that conflict, civilians on the

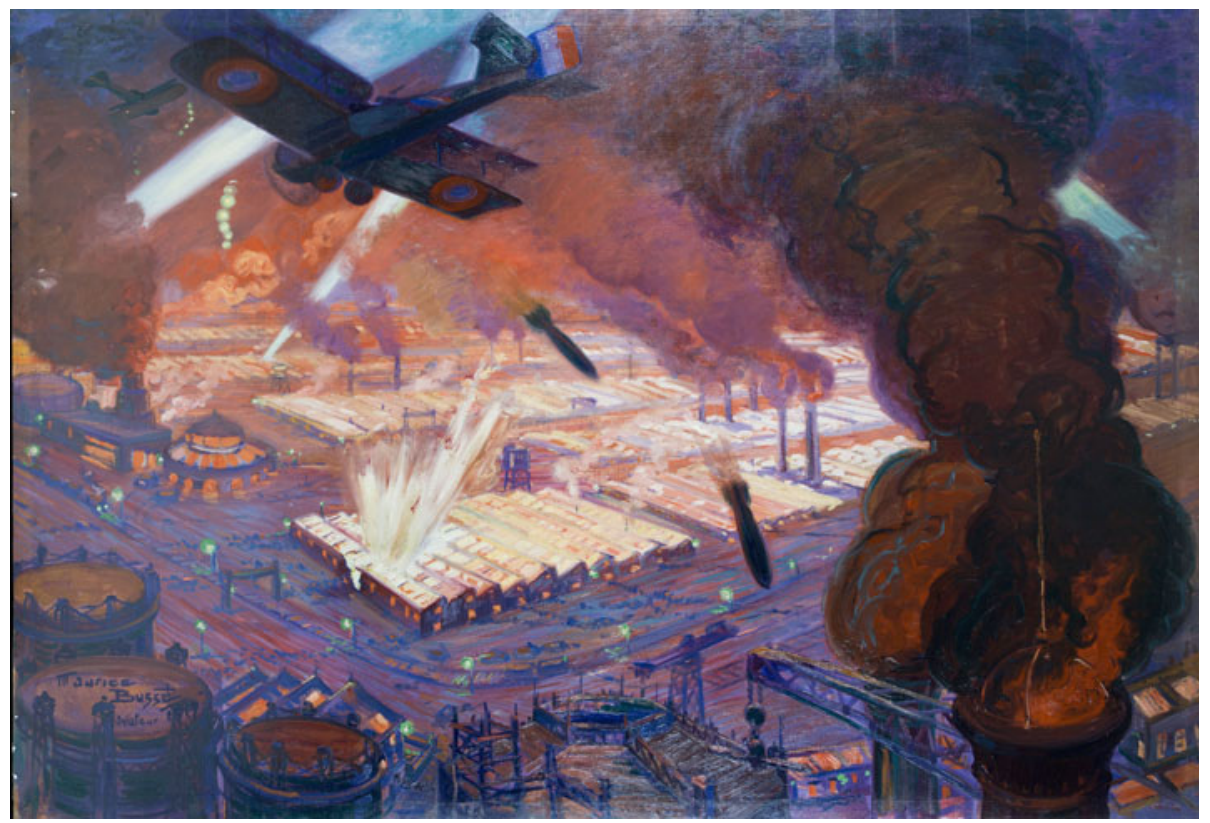

Figure 1. Maurice Busset, Bombardement de Ludwigshafen, 1918. Army Museum, Paris.

1 See Jay Winter (ed.), The Cambridge History of the First World War, Cambridge University Press, Cambridge, 2014. 
other side were simply the enemy (although Busset did not actually include any civilians in the image, as if they simply did not exist). In this way, it exemplifies the terrible novelty of total war. There was now more than one kind of front: sprawling military fronts mostly made up of men in uniform, and home fronts, where civilians came to be seen as targets, but their suffering went largely unnoticed and was often forgotten. himself:

In 1917, the poet Apollinaire, a soldier in the war, was already asking

What should this war be called? In the beginning, people called it 'the war of 1914 ', then as the war carried on into 1915 it became 'the European war'; when the Americans got involved it became the 'World War' or 'Universal War'. ... The 'Great War' has its backers too. The 'War of Nations' could garner some votes. The 'War of the Races' might also be defensible. And the 'War of the Alliances' or the 'War of the Peoples'. But the 'War of the Fronts' would perhaps express best the character of this gigantic struggle. ${ }^{2}$

For 100 years, the military fronts - land, sea and air - and those who fought on them have quite rightly received the most attention in discussions of conflict. But it is time to study everyone else's war. Civilians were also caught up in the fight - through their tremendous work to keep the supplies moving to the fronts where they were needed - and they suffered and grieved their losses. The military fronts cannot be understood without looking at those fighting on the home fronts, who also were completely mobilized for the war effort. Every man, woman and child contributed in his or her own way in factories, fields and schools.

The military fronts and the home fronts formed an immense, complex war machine: there were fronts on land, sea and air; there were sites of invasion and shelter, of Herculean labour, of military and civilian imprisonment, of tireless battles against wounds and disease, and of mourning and remembrance. This sowed the seeds of later catastrophes. In some areas, civilians were at the heart of the war; invaded, occupied, looted and bombed, they had become everyday targets in a total war. In these areas, outside the four walls of their laboratory, the authorities tested their ideas of how to repress large groups, displace entire populations, even attempt, in the words of the International Committee of the Red Cross (ICRC) at the time, the "systematic extermination" of the Armenians of the Ottoman Empire.

In his essay, "Wars of the Twentieth Century and the Twentieth Century as War", the Czech philosopher Jan Patocka fully grasped the paroxysmal nature of the conflict:

The First World War is the decisive event in the history of the twentieth century. It determined its entire character. It was this war that demonstrated that the transformation of the world into a laboratory for releasing reserves 
of energy accumulated over billions of years can be achieved only by means of wars. ${ }^{3}$

Emmanuel Levinas, a Lithuanian philosopher exiled from his country for the first time as a child in 1914, spoke of the importance that the two world wars had had on his life:

The war of 1914 never ended; the revolution and the unrest afterwards, the civil war, all of that comes together in the war of 1914 .... The unrest started in August 1914 and never stopped, as if the order of things had been forever disturbed. ${ }^{4}$

Both thinkers point the way to how we should explore this laboratory of violence, the "unrest", the "disturbances" and the extremely difficult task of perceiving, conceptualizing and remembering what happened.

The Great War was, whether deliberately or unconsciously, a laboratory for the twentieth century: a field experiment or test site where violence could be carried out and the effectiveness of military materials to kill men measured and improved. As weapons became increasingly sophisticated, the white-coated technicians were sometimes located right at the front. When poison gas was deployed on a massive scale for the first time, Fritz Haber, a German chemist, was on the battlefield at Ypres to observe the consequences of his research at first hand. Psychologists set up laboratories as close as possible to the action to use war as an extended experiment, with men serving as lab rats. Experts like these became proselytizers of total war, a way of waging war ever more effectively in the service of their countries. The goal of the laboratory war was not universal knowledge but national victory. On the military fronts, that meant many more captured, wounded or dead. Total war meant globalization and industrialization; modernization and regression; atavism, anomie and cultural appropriation across regions, countries and continents. Facts and statistics are needed on an enormous scale to assess the Great War - but geography and statistics do not bleed. We will endeavour, therefore, to understand the blood and the tears by looking at this new face of war on both the military and the home fronts.

\section{The military front}

Generals Hindenburg and Ludendorff coined the term "battle of materials" (Materialschlacht) to describe the battle of the Somme. Their soldiers, however, described it as Verwüstungschlacht: devastation or butchery. Officers of the General Staff and soldiers in the field were both right. Between 1914 and 1918, the various armies were engaged in battles of materials and battles of utter

3 Jan Patocka, Heretical Essays in the History of Philosophy, Carus, Chicago, IL, 1996 (first published 1975), p. 134.

4 François Poirié, Emmanuel Levinas, qui êtes-vous?, La Manufacture, Lyon, 1987, pp. 63-65. 


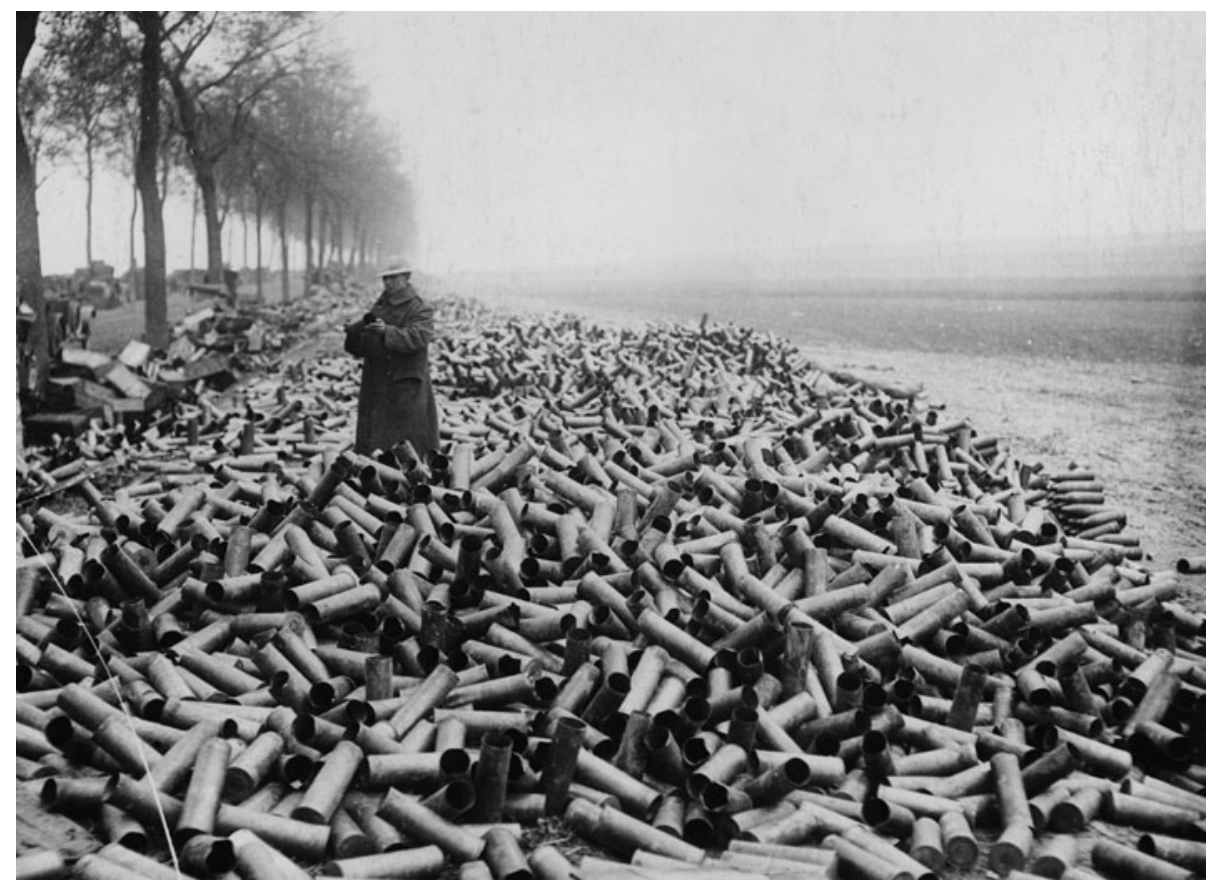

Figure 2. Tom Aitken, "Photo of a Soldier Surrounded by Shell Casings". National Library of Scotland.

carnage. The more than 70 million soldiers fighting the war were trapped in a new kind of deadly violence. Even if they came out of the war in one piece, over half of those that survived developed psychological disorders, minor and major.

From 1914, the battlefield became a place that was radically different and more terrifying than anything that had gone before. War had been transformed. Where previously soldiers had fought shoulder to shoulder, they were now isolated, spread out across the terrain, hiding wherever a shell had made a crater. While all battlefields had been frightening in the past, nothing had come close to the total dehumanization of this war. The difference between the means of protecting oneself and killing others was massive: machine guns, artillery, flamethrowers and poison gas turned the terrain into killing fields. Men were not even safe in their bunkers underground.

The intense fighting lasted, on and off, for weeks, then months. But after the outbreak of hostilities in 1914, the initial period of battles that were brutal but brief was over. Battles on the Western Front, on the Eastern Front and in the Middle East would last for months. They became a series of sieges that laid waste to everything around them - without, however, preventing in the least the besieged from bringing in new supplies and reinforcements, or rebuilding their defences. Rear lines of trenches extended so far, sometimes dozens of kilometres, that defending forces could repel almost all the enemy's attempts to break through. But how many 
were killed or wounded? How many were made prisoners of war? How many were declared missing or used as human shields?

As a result, what is most remembered about the war is the mass slaughter of combatants: over 10 million dead in four and a half years. Unlike in previous wars, very few died of disease; almost all were killed in the fighting. The survivors did not fare much better. Nearly $50 \%$ of all those who fought were wounded, whether seriously or not, and often more than once. Shells were the main cause; poison gas, though a new terror, caused far fewer casualties.

The new violence got under the skin and into the flesh of those who were both agents and patients. However, few would later be able to say "I survived, and I killed" - like Blaise Cendrars, the Swiss writer who volunteered to fight in the French army:

All at once everything breaks, cracks, booms. General commotion. A thousand blasts. Infernos, fires, explosions. It's an avalanche of cannon. The thunder rolls. Barricades. The firing pin. In light of the looming departure, oblique, ambiguous men, the index of a signboard, a crazy horse. The batting of an eyelid. The flash of magnesium. A quick snapshot. Everything disappears. ${ }^{5}$

"Everything", it seems, including bodies:

$[\mathrm{H}]$ e was blown up by a shell and I saw, with my own eyes I saw, this handsome legionary sucked up into the air, violated, crumpled, blasted in mid-air by an invisible ghoul in a yellow cloud, and his blood-stained trousers fall to the ground empty, while the frightful scream of pain emitted by the murdered man rang out louder than the explosion of the shell itself, and I heard it ringing still for a long moment after the [vaporized] body had ceased to exist. ${ }^{6}$

It was because there was so often no identifiable trace of killed men that governments started to commemorate the Unknown Soldier.

Innovations in general medicine in the nineteenth century led to improvements in military medicine. Therapeutic practices had seen progress too-paradoxically because of new kinds of wounds and injuries. Wounded soldiers were now commonly evacuated to field hospitals, where operations would be carried out with antiseptic agents and anaesthetics, reducing the risk of gangrene and amputation. Bullets and shrapnel were located using X-rays. Doctors performed reconstructive facial surgery. The first blood transfusions took place and new vaccines were developed. But the intensity of the fighting caused extreme emotional and psychological trauma, and left some irreversibly damaged. Psychiatric science was not sufficiently developed to treat stress and trauma of this kind. While German had the scientific-sounding Kriegsneurosen, the far less sophisticated-seeming "shell shock" of the British and obusite of the French (obus

5 Blaise Cendrars, "J'ai tué", in La Main coupée et autres récits de guerre, Denoël, Paris, 2013, translated as "I Killed" by Rainer J. Hanshe in Hyperion - On the Future of Aesthetics, Vol. 9, No. 1, 2015, Contra Mundum Press, New York, p. 22.

6 Blaise Cendrars, The Astonished Man, Peter Owen, London, 2004, pp. 18-19. 


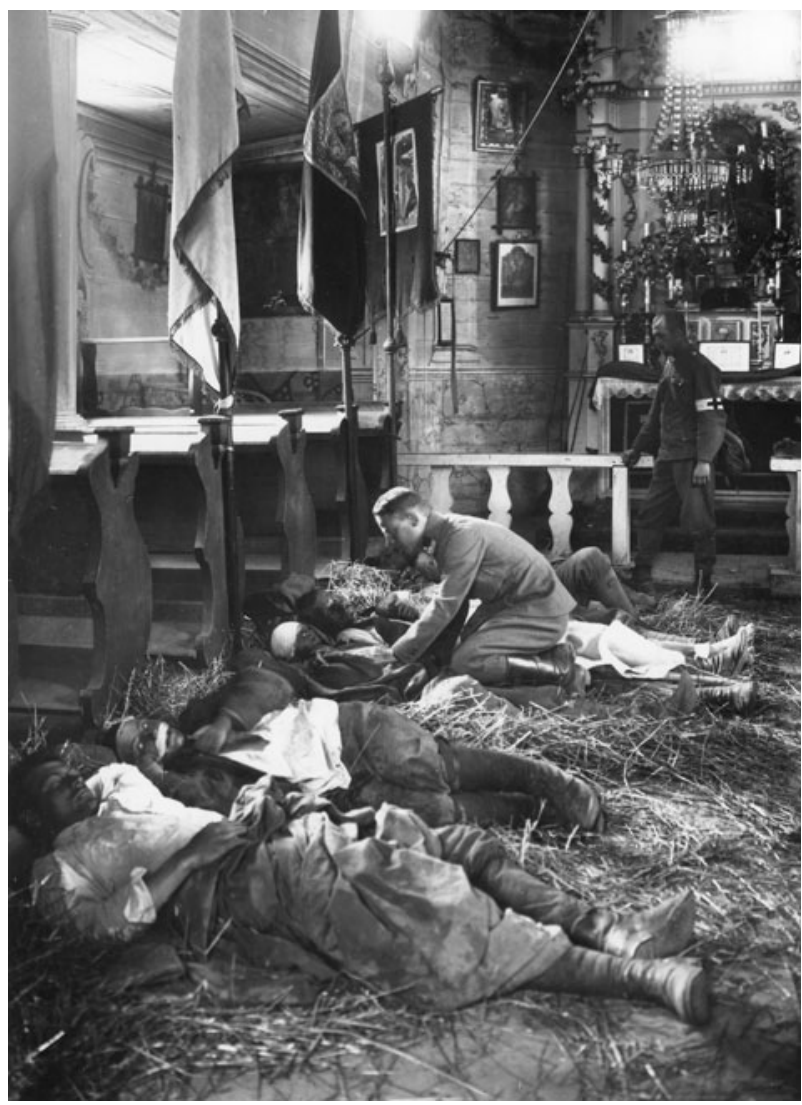

Figure 3. "Wounded German Prisoners of War", 1916. Archives of the ICRC, Geneva.

means "shell") left considerable room for unhelpful interpretation; in an atmosphere of feverish patriotism, combatants were frequently suspected of dissimulation. Nevertheless, little by little the experts had to accept the evidence before their eyes: not only did war mutilate men, it drove them mad. Even officers whose sense of honour and duty were beyond question could crack. For the philosopher Walter Benjamin, the generation of 1914-18 "had to experience one of the most monstrous events in the history of the world". 7 He insisted on the insignificance of human beings in this radically new kind of war:

A generation that had gone to school in horse-drawn streetcars now stood in the open air, amid a landscape in which nothing was the same except the clouds 
and, at its centre, in a force field of destructive torrents and explosions, the tiny, fragile, human body. ${ }^{8}$

What he hadn't understood, however, was that civilians had had their own fair share of frenzy.

\section{The home front}

In occupied areas, the usual dichotomy between front and rear did not exist. In "normal" wars, wives and daughters "stayed at home" while the husbands and grown-up sons went off to fight at the front. But in war, men-franc-tireurs, or maverick soldiers - would invade houses and women's bodies, venting their frustration on defenceless civilians. Hence the general fury against the Germans because of their atrocities in Belgium and France, against the Austro-Hungarians in Serbia, against the Russians in eastern Prussia.

A consequence of making war total was that immense numbers of people were now forced to flee their village or town - to live, or die, elsewhere. At both the start and the end of the Great War, there was an exodus of people by road and rail-people on foot and horseback, people crammed in carts, cars and trains. Though displacements were as old as war itself, the Great War made them commonplace, and ushered in the century of the refugee.

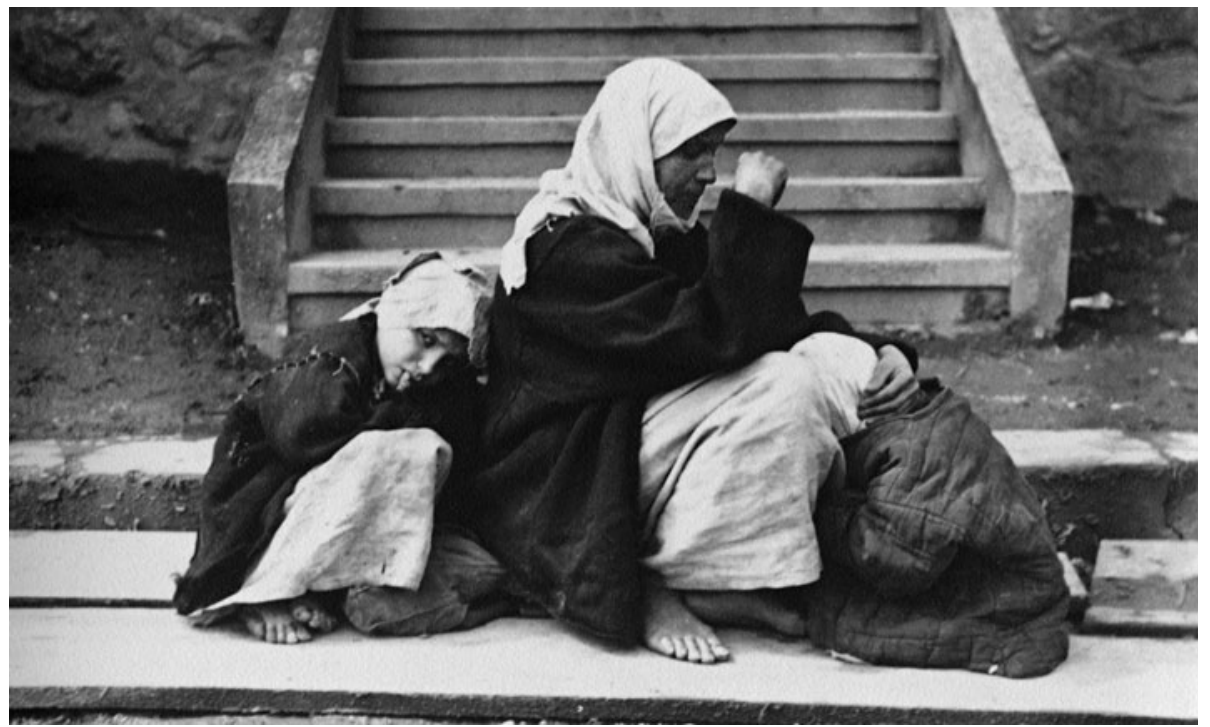

Figure 4. "Serbian Refugees". Archives of the ICRC, Geneva. 
In the beginning, people were fleeing at the approach of invading armies, holding onto the more or less reasonable hope of returning soon, depending on the country and the way the war was going. They knew, or hoped, they would be coming back, just as soon as the war was over. But when would that be? Louis Malvy, the French interior minister, gave this tortuous description of the situation of masses of people on the fringes of the war, who had lost their houses, jobs and resources:

There is obviously no uncertainty concerning the inhabitants of places in areas occupied by the enemy (whether they have withdrawn thereto or been repatriated thereto from Germany); nor is there any with regard to communes that, although located in an uninvaded or recovered area, have been evacuated by decision of the military or administrative authorities. The same cannot be said for inhabitants of communes that, unoccupied by the enemy and unevacuated, are located in an area that has to a greater or lesser extent been subjected to bombardment. ... There may be individual cases that require examination; that is to say that inhabitants, having left their place of residence, found themselves in a situation that, whilst justifying their departure, thereby too provides the grounds for their transfer elsewhere. ... These cases cannot be settled a priori by myself, and will therefore require referral to the prefects in the area of the military operations concerned for their assessment, who have hitherto always provided the most well-founded and equitable response to questions of this order. Should there be any doubts with regard to the situation of the interested party, the decision taken should be that which is the most generous and humane. ${ }^{9}$

These were men who were old or who had not been called up, and women and children. They were neither at the front nor at the rear, but somewhere else, in a new situation that paradoxically pushed them to the margins of the war simply because they had been, from the very first days and months, right in the eye of the storm. Many continued to be pushed from place to place; the evacuations and expulsions continued for the duration of the war, and these journeys were as diverse as they were painful. Those being displaced knew when they left that their houses would be occupied by soldiers. They hoped that these would be people from their own side in the rear lines, but what if they were enemy soldiers from the front? The enemy were barbarians, capable of anything - or so they thought, because that, after all, was why they were running away.

These men, women and children, when they did find refuge, attracted various reactions - the best and worst of societies during wars. The care and concern of the first months, bolstered by patriotic declarations of solidarity, soon gave way to rejection as the war dragged on. Refugees became a burden; they were useless, poor, extra mouths to feed-in short, foreign. Refugees did not 
simply have a different nationality: they were fundamentally alien. They could not be integrated into society. The perspective shifted from refugees coming from somewhere else to refugees being determined by something else. In the language of the day, that meant race.

On the Balkan, Ottoman and Eastern Fronts, invasions, counter-invasions and forced displacements made the movement and suffering of civilian populations even more dramatic. In 1914 the Russians advanced east, causing panic and terror, before the Central Powers turned the tables and thrust, in the summer of 1915 and after the Revolution in 1917-18, into the diverse immensity of Russia. As empires reorganized themselves internally, some displacements took the form of forced homogenization, reassembling and reordering society on social or racial lines. In Russia, the military had no qualms about how to treat "suspect populations" Jews and subjects of German origin. They were locked up or transferred well away from the front. This "ethnic cleansing" marked a turning point: from being internal refugees, many were now deportees.

A wave of pogroms coincided with other widespread violence by combatants against Jews, nourished by long-held ideas among the peasants of the Jews as "traitors", "infidels", "hoarders" and "speculators". The authorities ordered the courts not to prosecute: people could "have a crack at the yid" with impunity, and many regular

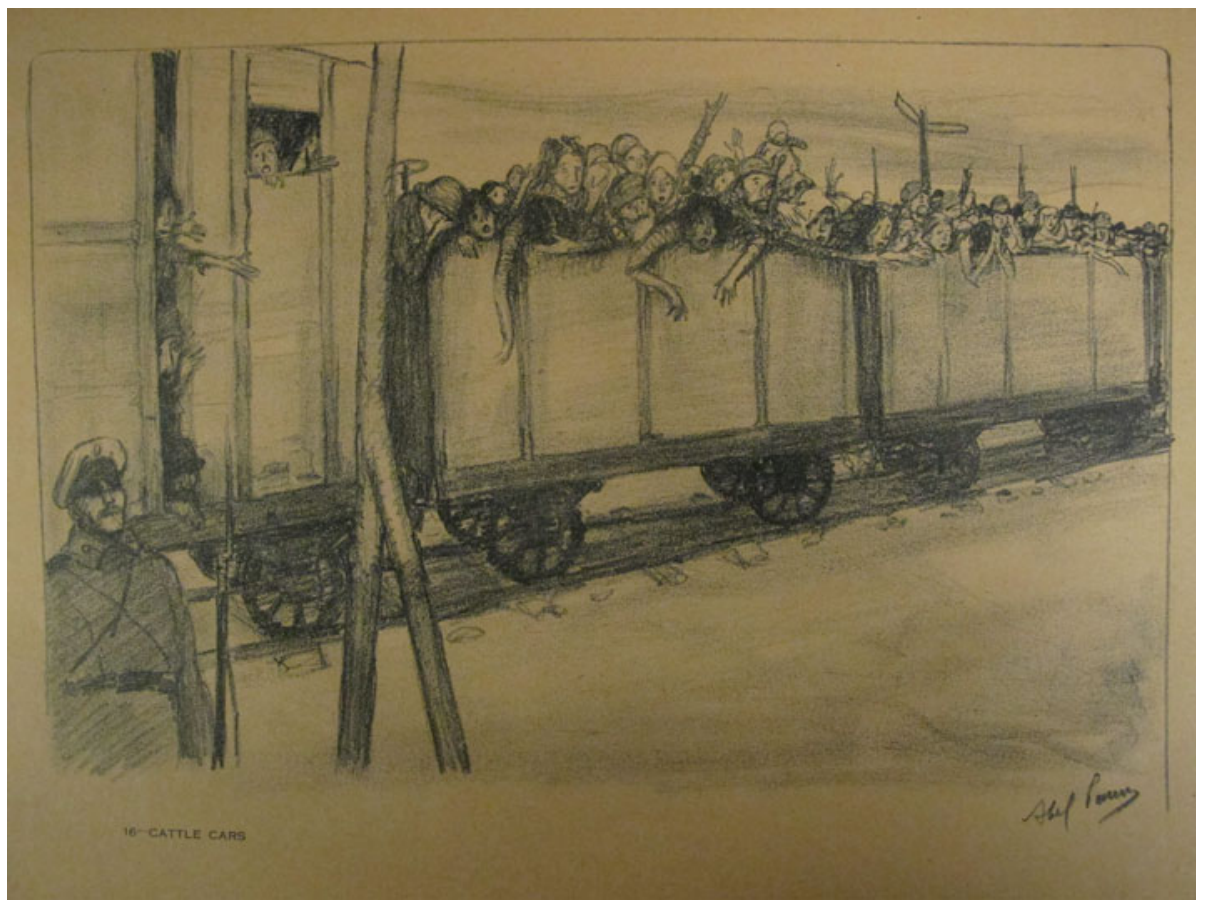

Figure 5. Image from Abel Pann, In the Name of the Czar: 24 Original Pictures, American Jewish Chronicle, 1918. 
military units committed war crimes. ${ }^{10}$ Waves of anti-Semitic violence continued on a massive scale between 1918 and 1920, as boundaries shifted and territories were carved up. The refugee could be said to be both the first to suffer in the war and the last.

\section{Concentration camps}

In 1917, Gustave Ador, the president of the ICRC, said:

Civilian internees are an innovation of this war; the international treaties did not foresee it. At the beginning of the war it may have been logical to immobilize them in order to detain suspects; a few months would have sufficed, it would appear, to separate the wheat from the chaff.

We must, from different points of view, integrate civilian internees with civilian deportees in enemy countries, as well as the inhabitants of territories occupied by the enemy. These civilians have been denied their liberty, and their situation differs little from that of the prisoners.

After three full years of war, we ask that the different categories of civilians in this war be the object of special attention and that a resolution to their situation, which in some regards is crueller than that of military prisoners, be seriously considered before the arrival of the fourth winter of this war. ${ }^{11}$

The war raised many questions. What should we call people who were in a particular geographical situation because of the conflict going on around them, who did not run away in time, who had become refugees and who had sometimes been captured and then locked up? "Internees"? "Deportees"? "Prisoners"? What should we do with them? They were not soldiers; there was, therefore, no international treaty to protect them.

Although "normal" war always involves the violent separation of civilians from soldiers, who may be wounded or die, the elation of heroism and the consent given to fight for one's country may in part compensate for the soldier's suffering. But there was none of that here: no heroism, no consent. There was just pure suffering on the part of civilians, made worse by the authorities' inability to uncover abuses or identify the victims. The administrative and military texts simply said "captured civilian"; there was no mention of gender or age, and their specific situation was simply ignored. That was the paradox facing civilians in prison camps. The war homogenized their cases and favoured combatants. The landscape of the Great War was scarred by concentration camps, watchtowers and barbed wire - which was at times electrified. But in a world in which heroes

10 Nicolas Werth, "Dans l'ombre de la Shoah, les pogroms des guerres civiles russes", introduction to Le livre des pogroms: Antichambre d'un génocide, Ukraine, Russie, Biélorussie, 1917-1922, Calmann-Lévy, Paris, 2010, pp. 36-37.

11 Speech at the International Conference of the Red Cross on the issue of civilian prisoners: ICRC Archives, 411/10, "Introduction sommaire à la question concernant les civils", September 1917, p. 1. 


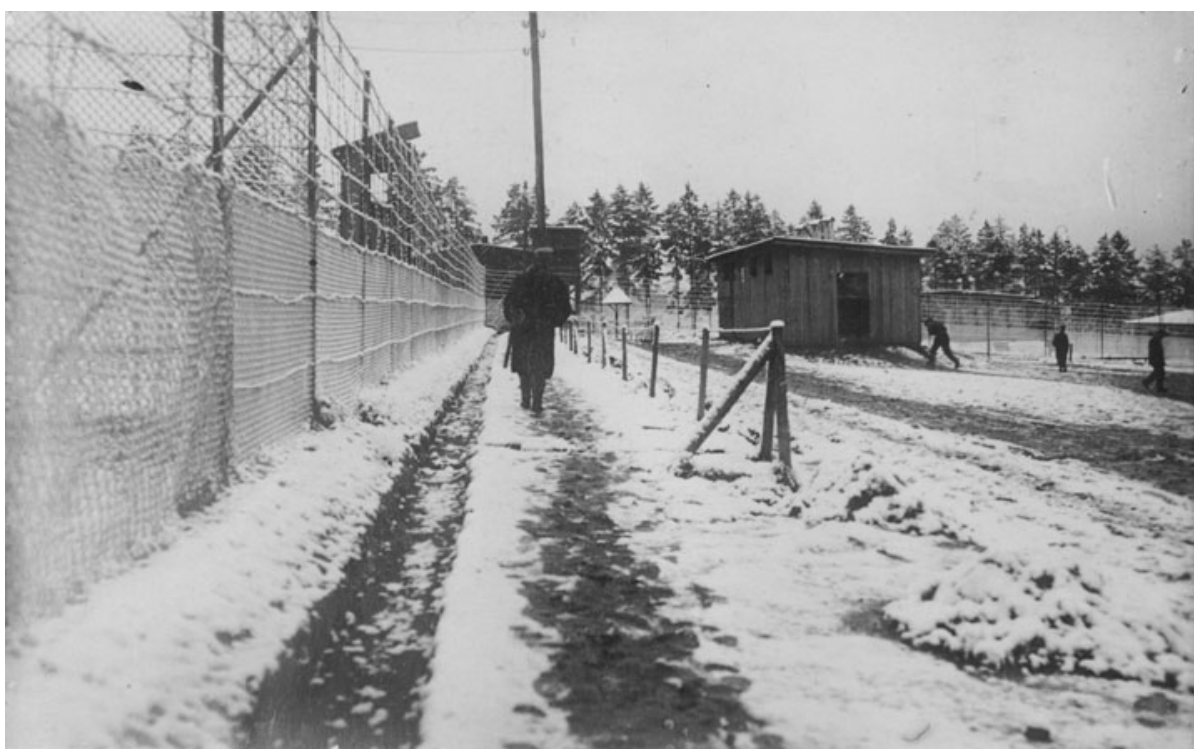

Figure 6. "Holzminden". Archives of the ICRC, Geneva.

were dying on the battlefield, few paid the civilian internees any attention. Civilian victims were marginalized, practically invisible. ${ }^{12}$

"Deportation" became synonymous with "concentration camps". It was normal to displace people as a way of forcing them to work or keeping them under surveillance, often as a form of punishment. Detention was administrative and/or military, never judicial, because the deportees were never tried or sentenced. The word deportatio in classical Latin ("cart", "carry away") came to mean "expulsion" or "exile" in Late Latin. The modern term blends both meanings, combining being taken from one's home and being expelled. Already before the war, the concepts of deportation and concentration camps were being fused by the means that made them possible - railways - and the objective: the separation of civilians - old men, women and children - from soldiers, so that the former would not "bother" the latter because of their family ties. This went on in a context of social Darwinism that grew out of colonialism: concentration camps had been invented by the Spanish in Cuba in 1896 and almost simultaneously reinvented in South Africa by the British during the Boer War.

Because Europeans had immediately made the war global by attacking other countries' colonies and calling on their own to come to their aid, concentration camps existed throughout the world in 1914. Civilian citizens of countries that had become enemies were labelled "enemy aliens" and interned in camps not only in their home countries but also in the colonies (e.g., Ukrainians in Canada, Germans in Australia, Galician Poles of Austria-Hungary in France). 


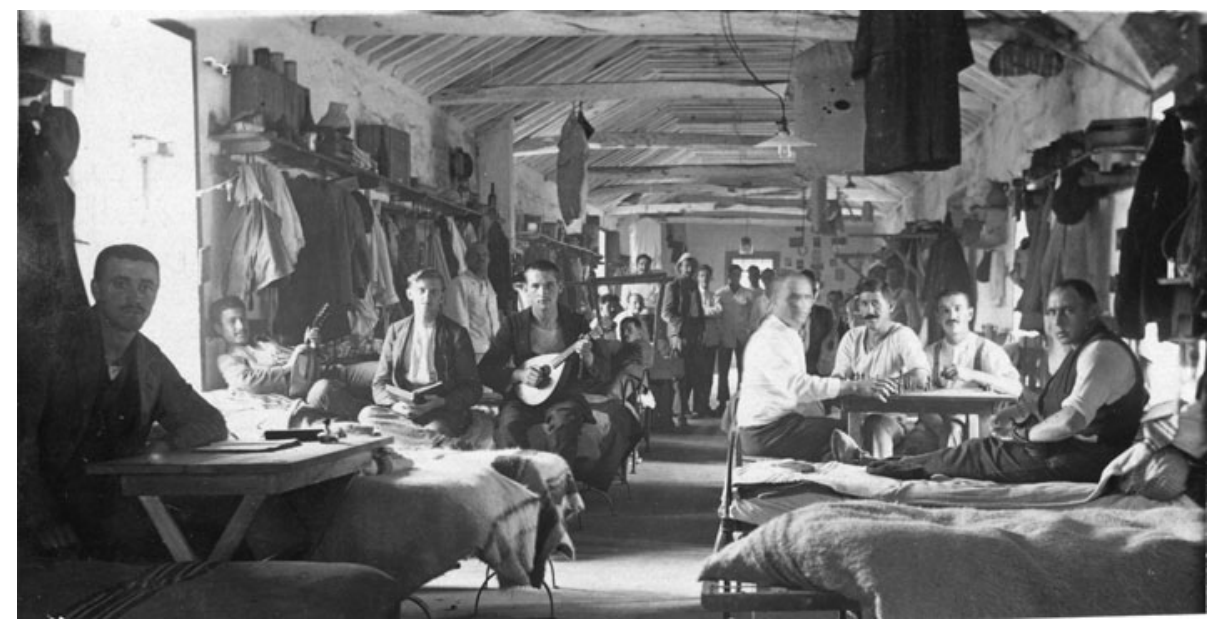

Figure 7. "Civilian Prisoners in Portugal". Archives of the ICRC, Geneva.

Men were the main target. Those who were of fighting age were seen as potential spies. Paradoxically, those of fighting age thus interned were saved from death at the front by this decision, however arbitrary it may have been. They were deemed to be military prisoners, saved from the trenches by capture and the original Geneva Convention.

Men and women soon suffered the same fate of deportation, something that was coming to be viewed as normal, even banal, as early as 1914. John Reed, an American journalist, caught the mood of the time:

Everybody kept up an incessant and anxious discussion as to whether Greece and Bulgaria would intervene, and on what side. For at any moment they might be cut off from home and condemned to perpetual wandering on neutral seas; they might be captured on landing and penned into concentration camps; they might be taken off the ship as alien enemies by a hostile cruiser. ${ }^{13}$

The populations of areas that had been invaded and then occupied by enemy armies formed a second group of civilian prisoners, who suffered different kinds of alienation and internment. This ranged from being isolated from their compatriots to being deported to concentration camps where, in some circumstances, they were held as hostages or subjected to forced labour. The major problem facing the economies of the warring countries was a shortage of manpower. Global, total war required global, total means. But if men had been mobilized en masse, women, prisoners of war and colonial workers in Great Britain and France were needed on the home front. The Central Powers turned 
to forced labour in their occupied areas: Belgian and French miners, Lithuanian (Ober Ost) or Serbian lumberjacks and farmers. Thousands, in some cases hundreds of thousands, of Belgians, French, Germans, Italians, Romanians, Russians and Serbs ${ }^{14}$ suffered the same fate, in Europe and the colonies. This was not only forced labour but a return to a kind of slavery.

The presence of women in the camps was an extraordinary novelty of this war, which was peculiar in mixing soldiers with civilians, uniforms with everyday clothes. Women in dresses, their bundles of belongings in hand, seemed incongruous and, indeed, out of place. The things that civilian prisoners made as did their so similar and yet so different counterparts, the military prisoners show how much they tried to improve their everyday conditions materially and psychologically. They were fighting boredom and depression, so often the causes of "barbed wire disease", and doing time, the time in prison replacing that of the war. The handicraft of civilians caught up in the war is like the handicraft of the trenches: objects from the war to represent the war; objects from the camp to represent the camp. ${ }^{15}$

\section{The murder of a nation ${ }^{16}$}

The Armenians of the Ottoman Empire represent the most extreme case of civilian displacement during the Great War; indeed, the case was so extreme that there was no word at the time for their deportation-extermination. The catastrophe grew out of the Turkish dread that their national security was at risk and from the decision to begin "ethnic cleansing" - Christians in Anatolia being forced to make way for Muslim refugees from the Balkans. For the Young Turks, the Armenians were powerful traitors, an enemy within. They were represented as pests, as beasts, their humanity denied. They needed to be "taken care of", shorthand even then for murder. ${ }^{17}$ Talaat Pasha, one of the heads of the Committee of Union and Progress that ruled the Ottoman Empire, described these deportations, which began with the children, as logical retribution against "traitors", people who were obviously in the pay of Russia: "The expulsion of Armenians from our eastern provinces is a military necessity." 18

As is all too typical when groups decide on mass murder, the Turks blamed their own crimes on their victims and claimed to be defending themselves from these "civilized criminals", an oxymoron more apt as self-definition in this case.

14 The ICRC estimates that there were 100,000 Belgians and French people deported to Germany and Germans deported to Russia. Some Italians were deported close to their home villages or to camps, set up by the Austrians, which mixed civilian and military prisoners.

15 Nicolas Saunders, Trench Art: Materialities and Memories of War, Berg, Oxford, 2003.

16 This term was coined, in relation to the mass extermination of Armenians, by Arnold J. Toynbee, The Armenian Atrocities: The Murder of a Nation, preface by James Bryce, Hodder \& Stoughton, London, 1915.

17 Turkish document sent to Pope Benedict XV, Vatican Archives, ASV, Guerra 1914-1918, 244, fasc. 110; Vérité sur le mouvement révolutionnaire arménien et les mesures gouvernementales, Constantinople, 1916.

18 Berliner Tageblatt, 4 May 1916. 
When deportations of Armenians to Syria began in April 1915, nothing had been done to prepare for their arrival. It is probable that the Armenians were not expected to survive the uprooting, or the thirst, starvation, rapes and massacres along the way. Armin Wegner, a nurse in the German army, recorded a telegram exchange between the mayor of Aleppo and Talaat Pasha. The mayor asked: "Thousands of deported Armenians have arrived. What should I do with them?" To which Talaat is alleged to have replied: "The destination of the deportation is: nowhere." Wegner adds: "That was another name for the desert."19

Finally, in July 1915, camps were organized by the Aleppo Sub-Directorate of Deportees that handled the deportees when they arrived by train. The camps consisted of tents - when available, most were simply cloth hung to provide some shelter against the sun - and had no sanitary facilities or food; they were generally situated over 25 kilometres from the railway station, and had to be reached on foot. Famine and typhus were rife, doing the murderers' work for them before they emptied the camps, one by one, by sending the living further east or finishing off those who remained. The Ras ul Aïn site was described by some as a "death camp".

Even as early as 1915, the massacre of the Armenians was being called a "crime against humanity and civilization". But this was not an official term in international law at the time-that had to wait until after 1945 and the Nuremberg trials. This was a cry for vengeance raised by the Triple Entente against the Central Powers and their ally, the Ottoman Empire. But although the Allies made much use of these crimes against the Armenians during the war as damning propaganda, they were quickly forgotten once the war was over. There was a shift from the "banality of evil" to the "banality of indifference", 20 and silence.

\section{Conclusion}

The war began with many expressing their determination and willingness to take part, but these attitudes shifted to rejection and outright pacifism after the conflict. As Freud said as early as 1915, modern warfare had produced extraordinarily traumatizing situations that nobody was prepared for: the mutilated bodies, the death of so many young people-an entire generation lost - and the massive destruction of homes and of hope. A nineteenth-century vision of progress and civilization had left behind nothing but barbarity - cruelty, brutality, internalized violence expressed as visceral patriotism - which whether it was accepted or rejected, fought or given into, would be reflected and refracted in

19 Armin T. Wegner e gli Armeni in Anatolia, 1915: Immagini e testimoniaze, Milan, Guerini e Associati, 1996, p. 88.

20 Yair Auron, The Banality of Indifference: Zionism and the Armenian Genocide, Transaction Publishers, New Brunswick, NJ, and London, 2000. 
the post-war period, in the private sphere and in the political, literary and artistic worlds. $^{21}$

From his earliest work in the 1920s, the Polish jurist Raphael Lemkin was motivated by what had happened during the invasions and occupations of the Great War. In a report prepared for the Fifth Conference for the Unification of Criminal Law in Madrid in 1933, he proposed calling these specific offences against the law of nations "acts of barbarism" and "acts of vandalism". He had understood - although he did not put it as clearly then as he later did - that the extermination of a people was not a random act of cruelty but the essence of this kind of war against civilians and the desire to homogenize peoples and religions. Lemkin went as far as he could in 1933 towards finding a legal term that encompassed offences against cultures and against individuals because they belonged to certain groups. He was looking for a legal chain of reasoning that would enable such unprecedented acts to be punished.

Invasions, occupations, atrocities, deportations and massacres of civilians kept pace with the radicalization of the fighting on the battlefield, yet they have been practically obliterated from the collective memory of the war. It would take another war - a total war on an even greater scale - for the word "genocide" to be coined by Lemkin. Memory had been defeated. It was laid low by the hypercommemoration of those who were seen either as heroes or as victims of the trenches, and by collective amnesia with regard to all the others, including the Armenians and the prisoners of war. Who now remembers the fate of the British prisoners - mainly Indians - forced to march across the desert of Iraq, to die there in their thousands?

Raymond Aron spoke about those he believed had got it wrong post-1918: "The Second World War reminded us that memory which was too faithful was just as dangerous as forgetting. The best way to precipitate a catastrophe is to employ the means that would probably have prevented the preceding one." ${ }^{22} \mathrm{He}$ was thinking of the pacifists, who would no longer go to war under any circumstances, and those who had not understood that loyalty to the soldiers of the trenches was preventing people from thinking about the war to come - the military aspects of modernity, the tanks and the aerial bombardments. And yet Heinrich Vierbücher, a German who had served as a translator to General Liman von Sanders in the Dardanelles, had as far back as 1930 said that to deport civilians, women and children, to make them die of thirst, starvation and ill treatment, to slaughter them like cattle in the abattoir, was worse than the war of the trenches:

The 50 long months of terror engendered by the Great War did not reach their climax on the battlefields of Vaux and Douaumont but in the mountain passes

21 Nicolas Beaupré, Heather Jones and Anne Rasmussen (eds), Dans la Guerre 1914-1918: Accepter, endurer, refuser, Les Belles Lettres, Paris, 2015.

22 Raymond Aron, "Alain et la politique”, in Hommage à Alain, 1868-1951: Textes inédits, NRF Gallimard, Paris, 1952, p. 158. 
of the Caucasus, that Golgotha of the Armenians which lies beyond anyone's imagination of horror, beyond even the visions of Grünewald, Goya and Bruegel..$^{23}$

23 Heinrich Vierbücher, Was die kaiserliche Regierung den deutschen Untertanen verschwiegen hat, Armenien 1915: Die Abschlachtung eines Kulturvolkes durch die Türken, 1930, translated as Armenia 1915: What the German Imperial Government Concealed from Its Subjects: The Slaughter of a Civilized People at the Hands of the Turks, Armenian Cultural Foundation, Arlington, MA, 2006. 